УДК 81'366

ББК 81

DOI: https://doi.org/10.17308/lic.2021.2/3424

\title{
АФФИКСАЛЬНОЕ ФОРМООБРАЗОВАНИЕ РУССКОГО ИМЕНИ
}

\author{
И. А. Меркулова \\ Воронежский государственный университет
}

AFFIXATION DERIVATION OF RUSSIAN NOUNS

\author{
I. A. Merkulova \\ Voronezh State University
}

\begin{abstract}
Аннотация: в статье предпринята попытка пересмотра соотношения подсистем русской морфологии. Выделяются признаки различения словообразования, словоизменения и формообразования и предлагается формальный критерий их разграничения. При словообразовательной суффиксации меняется часть речи производного (точнее - его синтаксическая функиия, что зачастую приводит и к изменению части речи) по сравнению с производящим. При формообразовательной-часть речи и синтаксическая функиия неизменны. Дается определение грамматического формообразования, под которым понимается внутричастеречное аффиксальное образование, служащее для маркирования грамматических категорий той или иной части речи и образующее подпарадигмы морфологического слова. В соответствии с этим признаком выделяются следующие категории существительных и прилагательных: размерности, степени проявления признака, экспрессивности, собирательности, единичности, пола, невзрослости, подобия. Анализируются контрпримеры, объяснение которых связывается с необходимостью учета гетерогенного характера современной словообразовательной системы, состоящей из относительно самостоятельных, но взаимодействующих между собой подсистем - исконной подсистемы аффиксации апеллятивов (именно ее закономерности описываются), интернациональной подсистемы аффиксации, подсистемы аффиксачии онимов.
\end{abstract}

Ключевые слова: словоизменение, формообразование, словообразование, русский язык.

\begin{abstract}
Russian morphology. The features that allow to delineate word derivation, inflection and derivation of word forms are described and the formal criterion of their demarcation is offered. In the process of word derivation with suffixes a new part of speech is formed (or, more precisely, the syntactic function of the word changes and this leads to the change of the part of speech). Inflection does not require any changes in the syntactic function and part of speech. The paper presents a definition of a grammatical form derivation - an affixation derivation which marks grammatical categories of a particular part of speech and creates subparadigms of a morphological word. The author analyses counter-examples and explains their existence by the necessity to take into account the heterogeneous nature of the modern word derivation system in Russian, as it includes relatively independent interacting subsystems: the original subsystem of the affixation of appelatives (the regularities of which are being analysed), the international subsystem of affixation and the subsystem of onym affixation.
\end{abstract}

Key words: inflection, form derivation, word formation, the Russian language.

\section{Введение}

Для русской лингвистической традиции характерно представление о морфологии как о части грамматики, преимущественно охватывающей словоизменение, при этом значения морфологических пока- зателей также рассматриваются в рамках морфологического описания. Словообразование обычно выделяется в отдельную область, промежуточную между морфологией и лексикой. Морфемика, определяемая как формальная морфология, либо рассма-

(С) Меркулова И. А., 2021

Контент доступен под лицензией Creative Commons Attribution 4.0 License.

The content is available under Creative Commons Attribution 4.0 License. 
тривается в связке со словообразованием, либо как переходная зона между морфологией и дериватологией, либо самостоятельно [1-3].

Как отмечают С. А. Крылов и С. А. Старостин, «необходимо переосмысление самой логики рассуждений, лежащих в основе традиционного разграничения основных сфер морфологии. Оно базируется не на одном критерии, а на целом пучке несовпадающих критериев, которые, однако, обнаруживают друг с другом некоторую устойчивую статистическую корреляцию» [4].

\section{История вопроса}

Граница между словами и словоформами определяет границу между словообразованием и формообразованием. Однако сложно провести эту границу четко и однозначно. Свидетельством этого являются многочисленные теоретические исследования, посвященные анализу данной проблемы [см., например: 5-8].

Начиная с работ Ф. Ф. Фортунатова, Л. В. Щербы и В. В. Виноградова, отчетливо проявляется тенденция к более четкому и соответствующему языковым фактам различению не двух, а трех типов морфологической деривации и выделению, наряду со словоизменением и словообразованием, области формообразования. Данную позицию «трихотомии» занимает и ряд исследователей конца ХХ в. [7-9].

В концепции Ф. Ф. Фортунатова разграничение словоизменения и словообразования основано на двух признаках: функциональном (формы словоизменения обозначают «различия в отношениях тех предметов мысли, которые обозначаются данными словами, к другим предметам мысли в предложениях», тогда как формы словообразования обозначают «различия в самих предметах мысли, обозначаемых словами») и формальном (формы словоизменения приравниваются к формам флексий) [10, с. 155]. Очевидно, что эти признаки существенно ограничивают область словоизменения по сравнению с теми потенциально возможными пределами, в которых слово, изменяясь грамматически, не перестает быть самим собой и, наоборот, неоправданно широко толкуют явления словообразования.

Формообразование в трактовке Л. В. Щербы связано со значительным расширением круга форм одного и того же слова. «Так, будет ли столик формой слова стол? Это не так уж ясно, хотя в языковедении обыкновенно говорят об уменьшительных формах существительных. Предобрый, конечно, будет формой слова добрый, сделать будет формой слова делать...» $[11$, с. 77]. Таким образом, у Л. В. Щербы понятие формообразования выходит за рамки форм флексии слов, вбирая в себя формы, образованные посредством префиксации и суффиксации, формально - средствами словообразования. Расширилось и понимание функциональной стороны: понятие форм одного слова связывается с обозначением одних и тех же предметов мысли в разных аспектах или с разными дополнительными значениями. А. И. Смирницкий полагал, что «грамматическая форма и грамматическая его оформленность - не одно и то же, хотя это связанные между собой явления. Грамматически оформленным является каждое слово, хотя не всякое слово выступает в какой бы то ни было определенной грамматической форме» [12].

В. В. Виноградов к определению форм слова добавил семантический критерий: «Грамматическими формами слова называются те видоизменения одного и того же слова, которые, выражая одно и то же понятие, одно и то же лексическое содержание, либо различаются дополнительными смысловыми оттенками, либо выражают разные отношения одного и того же предмета мысли к другим предметам того же предложения» [13, с. 35]. Однако семантика сама по себе не может быть надежным критерием определения различий между словоизменением и словообразованием. Это признавалось позднее и самим академиком В. В. Виноградовым, отмечавшим, что граница между новым понятием и оттенком того же понятия - зыбка, и само сознание говорящих при решении этого вопроса не всегда является надежным судьей. Действительно, семантика не объясняет, какие основания позволяют считать слово, отличающееся дополнительными смысловыми оттенками, только формой производящего слова, а не отдельным словом; неясно, какие именно дополнительные оттенки не создают нового слова.

В ряде исследований 1970-х гг. отчетливо прослеживается мысль о необходимости не ограничивать понятие формообразования формами одного слова, и тогда формообразование и словообразование оказываются не взаимоисключающими, а частично накладывающимися друг на друга понятиями [7; 8; 14]. «Таким образом, понятие формообразования охватывает словоизменение (словоизменительное формообразование) и, кроме того, формообразование несловоизменительное, т. е. сочетающееся со словообразованием (классификационное, или словообразовательное)» [7, с. 5].

В 1970-80-х гг. велась активная работа по выделению словообразовательного значения. Был издан ряд работ, в частности толково-словообразовательных словарей (3. А. Потиха, Г. П. Цыганенко, В. В. Лопатин, И. С. Улуханов, Т. Ф. Ефремова). Эти работы являются, безусловно, большим достижением словообразования, поскольку была осознана роль служебных морфем в формировании значения слова. Правда, проблема определения семантики аффиксов так и не была решена, а пригодного для компьютерного син- 
теза русских слов свода аффиксальных значений мы не имеем до сих пор.

А. И. Моисеев видит достаточным разграничение словообразования и формообразования, термин «словоизменение» используется им в качестве синонима к термину «формообразование» [15], что представляется неудачным по двум соображениям: 1) плодится синонимия, противопоказанная терминам; 2) необоснованно и «бесхозяйственно» игнорируются возможности разграничения понятий, представляемые русским языком.

А. С. Герд указывает на то, что формообразование и словоизменение являются разными по своему существу процессами: «словоизменение теснее связано с процессами психолингвистическими по природе» $[2$, c. 77]. О словоизменении можно говорить только применительно к флексиям, которые обслуживают именные и глагольные парадигмы. Основанием для разграничения словообразования и формообразования у А. С. Герда служит различие словообразовательных и формообразующих типов, в частности, словообразовательной и формообразующей основы. Для сочетаемости словообразовательной основы с морфемой определенного типа важны морфологические, лексико-семантические и в последнюю очередь фонетические (акустические) характеристики. Для формообразующей основы ключевую роль приобретают ее фонологический и акцентологический характер.

Поиск более четких критериев разграничения слово- и формообразования заставляет ученых вводить новые термины. Например, А. Л. Шарандин вводит понятие трансформов для обозначения особых словообразовательных форм, близких по содержанию к определению понятия «формы слова», структура которых включает в себя мотивирующее слово, отражающее то или иное явление действительности, и трансформатор, квалифицирующий данное явление с количественной или оценочной точек зрения. Такими трансформами у существительных, по мнению ученого, являются уменьшительные, увеличительные слова типа домик, домище. Тем самым А. Л. Шарандин, с одной стороны, различает парадигматическую технику - формы, и синтагматическую - трансформы, а с другой - включает те и другие в число словоформ данного морфологического слова, представляемого в словарях словарной формой (леммой). «Таким образом, термин “формообразование” оказывается общим для двух типов (видов) деривации, связанной с грамматикой и представленной морфологической и синтаксической деривацией. С целью их терминологического разграничения можно сохранить за морфологическим формообразованием термин “словоизменение”, а синтаксическое формообразование обозначить термином “трансформация”. Соответственно, в качестве их единиц выступают словоформы и трансформы» [16, c. 49-50].

Грамматическая концепция И. А. Мельчука, представленная в «Курсе общей морфологии» [17], опирается на понятия граммема (обязательное), дериватема (необязательное) и квазиграммема (необязательное, но регулярное). Автор рассматривает семь различий между словоизменительными и словообразовательными значениями, хотя у некоторых зарубежных лингвистов их количество измеряется десятками: в работе В. Дресслера упоминается 20 критериев [18], в работе Ф. Планка - 28 [19].

Попытку разграничения словоизменения и словообразования с помощью многофакторной шкалы, заданной рядом эвристических критериев, предпринимает Н. В. Перцов в книге «Инварианты в русском словоизменении» [20]. Автор показывает, что оппозиция словоизменения и словообразования носит градуальный характер и обсуждает свойство обязательности как важное проявление словоизменения, причем поддерживает идею Е. С. Масловой [21] о различении разных степеней обязательности. Н. В. Перцов предлагает шкалу различий словоизменения и словообразования, включенную в более широкий контекст - различение лексического и грамматического [20, с. 92]. На первый взгляд, такое решение представляется соответствующим объекту описания и хорошо известному положению об отсутствии четких и жестких границ в Универсуме, вообще, и языке, в частности. Однако фактически тем самым проблема о границах между словообразованием и морфологией просто переносится на лексико-грамматическую шкалу, а вопрос о критериях различения того и другого так и остается без ответа.

Свой подход, названный «неоструктуралистская парадигма», С. А. Крылов основывает на распределении морфологии по двум дихотомиям. 1. «Словообразование» vs. «формообразование». «Формообразованию присущи коррелятивность, композиционность, продуктивность, нефразеологизованность, стандартность, “"меньшая вероятность хранения в памяти как единого целого”. Словообразованию (лексикализации) присущи: некоррелятивность, некомпозиционность, непродуктивность, фразеологизованность, нестандартность, “большая вероятность хранения в памяти как единого целого" [4, с. 4]. 2. «Номинация» vs. «словоизменение». «Номинации (в том числе основообразованию) присущи: невхождение в состав обязательной категории, отсутствие связи с синтаксисом. Словоизменению (“инфлексии”) присущи: вхождение в состав обязательной категории, наличие связи с синтаксисом» [Там же]. В результате учета этих дихотомий получаются 4 множества (области) - номинационное словообразование, номинационное формообразование, словоизмени- 
тельное словообразование, словоизменительное формообразование. Названия указанных множеств, на наш взгляд, воспринимаются не однозначно. Так, например, говоря о словоизменительном словообразовании, можно подумать, что это случаи тапа раб-раба, лис-лиса, а также больной-больная (как субстантивированные прилагательные). Первые - реликты праимени, а вторые - синтаксические трансформы слов. Второе - уже синтаксис, а не морфология. Авторы же относят к словоизменительному формообразованию «творительный падеж существительных в качестве словарных наречий (бегом, босиком, голышом, нагишом, кубарем...); второе лицо единственного числа глаголов в качестве словарных междометий (шутишь!, шалишь!, вишь!, слышь!, врёшь!..); мужской род прилагательных в качестве словарных имен лиц (дежурный, пожарный, полицейский, часовой, постовой, участковый...); женский род прилагательных в качестве словарных названий «помещения» (столовая, прихожая, ванная, уборная, гостиная... булочная, парикмахерская, пельменная, бильярдная...); средний род прилагательных в качестве словарных названий блюд (мороженое, заливное, жаркое, сладкое, первое, второе, третье, жареное, соленое...)» [Там же].

То, что определяется как номинационное словообразование с учетом указанных признаков, является «чистым» композиционным словообразованием, исключающим компрессивную технику образования слов. К номинационному формообразованию авторы относят причастия, уменьшительные существительные (!), видовые пары с тривиально выводимыми значениями вида, залоги, плюральные образования.

Таким образом, этот подход порождает новые вопросы об отношении морфологии не только к словообразованию, но также к фонемологии, лексике и синтаксису.

Анализ литературы вопроса позволяет заключить, что словоизменение, словообразование и формообразование в русском языке, являясь областями грамматического, по-разному включены в морфологию, а критерии их различения требуют уточнения.

Словоизменение можно приравнять к парадигматической морфологии, формообразование - к синтагматической технике морфологии, а словообразование отнести к синтагматической лексике. Тогда многозначность окажется парадигматической лексикой, только формой ее проявления будут дефектность морфологической парадигмы и особенности лексико-синтаксической сочетаемости.

\section{Предлагаемый критерий}

Мы предлагаем разграничивать словообразование, словоизменение и формообразование по собственно морфологическому критерию.
В первую очередь, важно ответить на вопрос, что же считать словообразованием, а что - формообразованием, так как в этих процессах принимают участие аффиксы, в отличие от словоизменения, использующего флексии.

Как известно, в процессе суффиксации часть речи (и, что особенно важно, - синтаксическая функция словоформы в предложении) производящего слова может либо изменяться (кровь - кровавый, дружить - дружба, интерес - интересный и т. д.), либо оставаться неизменной (шуба - шубка, дом - домище, толстый - толстенный, альй - аленький, катать - катывать и др.).

При формообразовании парадигма слова остается неизменной, т. е. не происходит изменения грамматических показателей. При словообразовании в результате присоединения аффикса наблюдается смена парадигмы. В идеале каждый раз при присоединении аффикса должно образовываться новое слово с новой парадигмой, однако часто подобного не происходит: шуметь - зашуметь, нести - принести и т. д. Очевидно, что здесь можно с точностью говорить о формообразовании, поскольку парадигма обоих глаголов в паре остается неизменной. Как бы то ни было, здесь происходит присоединение аффикca, т. е. используется техника наращения основы.

В рамках традиционного словообразования (представителями которого являются Г. О. Винокур, Н. М. Шанский, И. С. Улуханов, Е. А. Земская, В. В. Лопатин, А. Н. Тихонов, Л. А. Араева, Л. В. Рацибурская) основным процессом, имеющим место в словообразовании, признана мотивация. Все слова по отношению друг к другу выступают в двух функциях: мотивируемого и мотивирующего. Помимо мотивации, которая определяется как «семантическая обусловленность мотивируемого значением мотивирующего», выделяют также словообразовательную производность, при установление которой учитывается формальная соотнесенность единиц.

Имеется и альтернативный подход, где основной процесс словообразования - деривация. Считается, что образование новых лексических единиц происходит не от слова, а от ЛСЕ (лексико-семантической единицы). Такое понимание термина деривация не относится к общепринятым. Мы вслед за А. А. Кретовым [22] понимаем ЛСЕ как единство семемы, лексемы и лексико-синтаксической сочетаемости, присущей данной семеме. Между ЛСЕ языка могут существовать деривационные отношения. Результатом процесса деривации является производная ЛСЕ, а единица, от которой образовано это слово, называется производящей. При установлении деривационных отношений необходимо соблюдать принцип историзма, состоящий в том, что производная ЛСЕ единица берется такой, какой она была на момент 
образования в породившей ее системе, что предполагает ориентацию не на семантическое сходство единиц, которое в результате исторического развития может утратиться, а на их форму и этимологические данные исторического развития слова. Представители традиционного подхода упускают звено или даже несколько звеньев деривационной цепочки, пытаясь найти слово семантически и формально «мотивирующее» производное (например, обобщая и отождествляя суффиксы =mель и =итель). При альтернативном подходе семантика также учитывается, но при этом отсутствует презумпция, будто все русские слова образованы «здесь и сейчас»: исследователи пользуются приниципом этимологической коррекциии (Т. Л. Ляхнович - Г. П. Мельников), обращаясь к исходному (словообразовательному) значению производного, устанавливаемому методом внутренней, а иногда и внешней реконструкции.

Словообразование всегда межчастеречно, существительное может быть произведено от глагола (косить - косьба, преподавать - преподаватель), прилагательное от существительного (чудеса - чудесный, лес-лесной, вага - важный), существительное от прилагательного (гордый - гордость), глагол - от существительного (взгляд - взглядывать, глаз - глазеть, кровь -кровить, хам-хамить, захват -захватывать) или прилагательного (белый - белить, хитрый-хитрить, зима-зимовать, ночь-ночевать).

Формообразование имеет место между единицами одной части речи. Морфема, участвующая в формообразовании, всегда несет грамматическое значение (дом-домик, чудо-чудеса). Наш критерий разграничения слово- и формообразования можно считать формальным, поскольку мы учитываем лишь частеречную принадлежность (точнее - морфологическую парадигматику) слов и ее изменение в процессе аффиксации (у имен - преимущественно суффиксации).

При словообразовательной суффиксации меняется часть речи производного по сравнению с производящим. (Строго говоря, меняется не часть речи, а синтаксическая функция, что обычно приводит и к изменению части речи.)

При формообразовательной - часть речи и синтаксическая функция остаются неизменны.

В качестве одного из критериев «склонность к сохранению/изменению части речи исходного знака» используется и Н. В. Перцовым. Критерий К9: «Присоединение словоизменительных показателей не меняет, как правило, часть речи исходного знака; присоединение словообразовательных показателей нередко меняет часть речи исходного знака» [20, c. 98]. Здесь же приводятся и контрпримеры - причастия, меняющие исходную основу глагола на прилагательное, деепричастия - на наречие. Правда, еще
Ф. Ф. Фортунатов, Д. Н. Ушаков и А. М. Пешковский относили причастия к прилагательным, а деепричастия - к неизменяемым словам (наречиям).

Это значит только одно: синтаксическую деривацию по Е. Куриловичу, традиционно относимую к словообразованию, русская грамматическая традиция относит к морфологии. Сюда же - происхождение инфинитива и необходимость включения отглагольных имен (типа yходить - уход) в парадигму глагола, о чем пишут представители Тамбовской лингвистической школы $[23 ; 24]$.

Синтаксическое словообразование - это способ свернуть пропозицию в один член предложения причастие (с оборотом), деепричастие (с оборотом), инфинитив и отглагольное существительное (тоже часто с оборотом: друзей моих медлительный уходБ. Ахмадуллина). Все это - способ соединить несколько пропозиций в одну. Это компрессивная техника синтаксиса, функционально аналогичная (но формально не тождественная) компрессивной технике словообразования: газированная вода > газировка.

При словообразовательной компрессии происходит сжатие двух слов в одно с тем же значением. При синтаксической компрессии происходит сжатие двух (и более) предложений в одно. Компрессию не следует путать с объединением двух простых предложений в одно сложное, хотя и там часто можно видеть в сложном предложении аналог простого, в котором определения или обстоятельства выражены придаточными предложениями: Деревня, где скучал Евгений, была прелестный уголок = Онегинская деревня / Деревня Евгения была прелестный уголок < Деревня [какая?] была прелестный уголок + Евгений скучал [в этой] деревне.

Случаи же сохранения части речи при присоединении «дериватемы» (которую корректнее именовать формообразующим суффиксом), например, диминутивы существительного, на наш взгляд, являются не чем иным, как суффиксальными маркерами грамматических значений, а следовательно - способом формальной категоризации прилагательных.

Поскольку лексика представляет собой высший уровень языка, которому подчиняются грамматика и фонетика, не удивительно, что кроме нашего (морфологического по форме и синтаксического по функции) обобщения словоформ, отвлекающегося от частичных морфемных различий в формах основ, образующих собственные парадигмы (именно эти парадигмы мы выделяем и описываем) и передаваемых формантами основ морфологических значений, возможна и еще более высокая ступень обобщения, основанная на формальном тождестве корня и функциональном тождестве лексического значения (в учении В. Г. Руделёва и А. Л. Шарандина о шифрующей роли грамматики и мимикрии грамматических форм) и сопро- 
вождающаяся абстрагированием от различий в грамматических основах и оформляющих их парадигм.

Наконец, третьим шагом на пути абстрагирования от формы во имя тождества номинативной функции (= тождества лексической семантики) является признание центральной единицей лексической системы не формальной единицы - слова, а функциональной единицы - лексико-семантического инварианта (ЛСИ), при котором снимается последнее требование тождества формы - требование тождества корня лексико-семантической единицы высшей степени обобщения - ЛСИ (разумеется, перед этим снимается и требование тождества морфологической формы и синтаксической функции).

\section{Верификация применяемого критерия}

В «Русском именном словоизменении» А. А. Зализняка было предложено первое полное описание именного словоизменения [25]. Мы предлагаем дополнить его описанием суффиксального формообразования. Вспомним, что еще А. А. Шахматов к морфологическим различиям относил не только систему падежных окончаний, но и различия в строении основ и, анализируя систему современного склонения имен существительных, попутно выделял все те грамматические категории, которые так или иначе связываются с разными явлениями в склонении имен [26].

Под грамматическим формообразованием понимается внутричастеречное аффиксальное образование, служащее для маркирования грамматических категорий той или иной части речи и образующее подпарадигмы морфологического слова.

В соответствии с этим признаком мы выделяем следующие категории существительных и прилагательных.

Категория размерности. Например, голос - голосок - голосище, деньги - деньжата - деньжищчи, дом - домик - домина/домище, карась - карасик карасище, мороз-морозец-морозище, блюдо-блюдизе - блюдище, поляна - полянка - полянищза и др. В ряду уменьшительных или увеличительных форм зачастую встречается более одного варианта диминутива или аугментатива. Например, рыбка-рыбешка, рыбищза - рыбина, голосище - голосина, домищче - домина. Это свидетельствует, на наш взгляд, о тесной связи категории уменьшительности-увеличительности с категорией экспрессивности. По поводу данных значений Н. В. Перцов отмечает: «Например, является ли набор значений (диминутив, аугментатив) обязательными для пар словоформ домик-домище, слоник-слонище, лапка-лапища и т. п.?

Строго говоря, является. Тогда хотелось бы исключить класс словоформ, входящих в такие пары, из числа тех, к которым вообще приложимо понятие обязательности соответствующей категории (чтобы не было соблазна счесть указанные значения словоизменительными)» [20, с. 73].

Логика этого рассуждения удивительна. 1. Выбор диминутива-аугментатива или немаркированной нейтральной формы «строго говоря, обязателен». 2. Из этого автоматически следует «соблазн» (т. е. строгая логическая необходимость) признать эти формы словоизменительными. 3. Но делать этого «не хотелось бы», а «хотелось бы исключить» их из обязательных.

Получается: если нельзя, но очень хочется («исключить»), то можно. Желание исследователя оказывается превыше логики и показаний языка.

И еще возникает вопрос, почему обязательность выбора только для пар словоформ? Скорее они выстраиваются в парадигму домик-дом-домище. Надо выбрать одно из трех. Этот выбор обязателен и, следовательно, грамматичен.

По мнению А. Л. Шарандина, в системе существительного имеется такая категория, как «способы представления субстанции (предмета) - это неграмматическая формообразовательная категория словообразовательно-модификационного типа, выражающая отношение к количественному ракурсу восприятия субстанции (предмета) и представленная противопоставлением рядов словообразовательных форм с морфемно характеризованными значениями собирательности, сингулятивности, увеличительности, уменьшительности» [16, с. 67-68].

У прилагательных эту категорию можно назвать категорией степени проявления признака. Таких степеней можно выделить несколько. 1. Ослабленная степень проявления признака. Семантически описывается с помощью сочетания «слегка + полное прилагательное». Бельй - беловатый, дорогой - дороговатый, слабый-слабоватый, грубый-грубоватылй, серый - сероватый, соленый - солоноватый, синий-синеватый, тощий-тощеватый. 2. Усиленная степень признака. Семантику таких слов можно описать с помощью сочетания «довольно-таки + полное прилагательное». К тому же такие прилагательные, как правило, эмоционально окрашены. К этой группе относятся следующие суффиксы: полнылй-полнёхонький, полнылй-полнёшенький, скорыйскорёхонький, скорый-скорёшенький, сытыли-сытёхонький, сытыли - сытёшенький, здоровыли - здоровёхонький, здоровый-здоровёшенький, живой-живёхонький. 3. Превосходная степень проявления признака. Семантика этой группы описывается сочетанием «очень + полное прилагательное». Строгийстрожайший, жалкий - жалчайший, ветхий - ветшайтий, великий - величайший, дорогой - дражайиий; первыци - первейший, мальй-малейший, простой-простейший, богатый-богатейший, новый- 
новейший, грубый-грубейший; толстый-толстенный, тяжельій - тяжеленный, широкий - иироченнылй, здоровый-здоровенный, высокий-высоченный; большой - большущзий, здоровый - здоровущчий, толстый - толстущзий, толстый - толстющчий, хитрыци - хитрущчий, хитрый - хитрющий, длинныц̆ - длиннюший, жадный-жаднюший, грязный-грязнющий, злой - злющий. 4. Нейтральная (или нормальная) степень проявления признака - не маркированная суффиксом. Точнее - со значимым отсутствием суффикса.

Формы же сравнительной степени прилагательного, в соответствии с принятым нами принципом, относятся к словообразованию, так как в случае слабый-слабее суффиксация ведет к смене морфологической парадигмы и что много важнее (ибо первично) - синтаксической функции: парадигма прилагательного меняется на нулевую парадигму, а функция определения - на функцию сказуемого. Более того, краткая форма прилагательного стала предикативной формой: Иван (есть/был/будет) выссок и Петр (есть/был/будет) выссок, но Иван (есть/был) будет) вылие, чем (есть/был/будет) Петр > Иван (есть/был/будет) выне Петра.

Категория экспрессивности представлена у существительного и прилагательного.

В основе этой категории лежит субъективное называние предмета. Брат - братец/братишка, папа - папка, папаня, папуля, папуся, папик, папочка, баба - бабуся/бабуля/бабуленька/бабусенька, дура дуреха, мама - мамка, мамаша, маманя, мамуля, мамуся, маманя и т. п.

Категория экспрессивности у прилагательных аналогична категории экспрессивности существительного. Эта категория маркируется суффиксами, имеющими ласкательное экспрессивное значение: альй - аленький, малый -маленький, молодой - молоденький, старый-старенький, худой-худенький, толстьй-толстенький, пегий-пегонький, плохойплохонький, сухой - сухонький, тихий - тихонький, тугой-тугонький, мальй-малюсенький.

Поскольку уменьшительность практически неотделима от ласкательности, уменьшительно-ласкательным суффиксам свойственно со временем утрачивать свою семантику (десемантизироваться), что ведет к необходимости «освежить» эту семантику прибавлением нового уменьшительно-ласкательного суффикса. Это приводит к расхождению внутренней формы слова (словообразовательного значения) и его актуального значения в лексико-семантической системе. Изменение первоначальной семантики слова нередко приводит к тому, что суффиксально маркированный член оказывается функционально (лексико-семантически) нейтральным, немаркированным: например, рюма - рюмка, кубыха - кубышка, игла - иголка, нож-ножик, рама-рамка. Наиболее очевидно это в случаях «стертой уменьшительности», т. е. формах существительных, которые в большей или меньшей степени утратили уменьшительное значение «в связи с исчезновением в языке соответствующего неуменьшительного слова» [27, с. 43]. На наш взгляд, это утверждение небесспорно. Действительно, значение уменьшительности в этих словах практически не осознается носителями языка, но лишь потому, что их неуменьшительные формы не употребляются в речи, но в языке они имеются и никуда не исчезали, о чем свидетельствуют данные словарей:

Булавка - булава; вершок-верх; ветка - веть (Срезневский); галка - гала (ср. галица); корица кора; крыльцчо - крыло; кромка - кром (Даль); кочка-коча; кузница - кузня; куманек-куман; куницакуна; лавка - лава (Даль); лодка - лодь (Срезневский); ляжка - ляга (Даль); мешок - мех (Срезневский); палка - пала (ср. палица); платок - плат; порошок - порох; пряжка - пряжь (Срезневский); пуговица - пугва (Срезневский); суслик - сусоль; хорек - хорь; щүетка - щеть (Даль); ящик - яскь (корзина) и др.

Неслучайно эти существительные со «стертым» значением уменьшительности требуют ее постоянного подновления и становятся производящей базой для других существительных с уменьшительным значением. Отсюда нанизывание суффиксов друг на друга и образование суффиксальных блоков: булав-

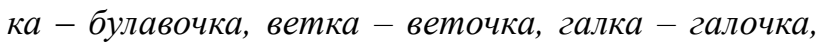
кромка - кромочка, кочка - кочечка, куманек-куманечек, лавка - лавочка, лодка -лодочка, ляюка -ляжечка, мечок-мешочек, палка - палочка, платокплаточек, порочок-порочочек, пряжка - пряжечка, пуговица - пуговичка, рамка - рамочка, щзетка щеточка, ящчик - ящичек.

К собственно субстантивным категориям относятся следующие

\section{Категория собирательности.}

Она имеет значение совокупного, обобщенного называния предметов. Мужик - мужичье, старикстаричье, брат - братия/братва, девка - девчата, мальиш-мальиня, мошка-мошкара.

Особенность категории собирательности-единичности заключается в том, что она представлена двумя видами противопоставлений. С одной стороны, собирательность противопоставлена несобирательности как маркированный член немаркированному, например, дурак - дурачьё, баба - бабьё, мужик мужичьё, зверь - зверьё, ворон - вороньё, комар комарьё, старик - старичьё, кулак-кулачьё, братбратия, аристократ - аристократия, лист-листья, листва, пацан - пацанва, брат - братва, солдат солдатня, шофер - шоферня, мальии - мальишн, девка/и - девчата. 
С другой стороны, собирательность противопоставлена единичности как немаркированный член маркированному, например, горох - горошина, бусы -бусина, виноград-виноградина, клюква-клюквина, картофель - картофелина, град - градина, жемчуг - жемчужина, солома - соломина, бисер - бисерина, баре - барин, граждане - гражданин и др.

Категория единичности (с парной ей категорией собирательности).

Служит для обозначения единичного предмета из совокупного нерасчлененного множества. Солома соломина, горох-горочина, бусы-бусина, жемчугжемчужина, баре - барин, дробь - дробинка, снег снежинка, дождь - дождинка.

\section{Категория пола.}

Маркирует слово со значением «представитель женского пола»: скрипач-скрипачка, голубь - голубка, мастер-мастерица, слон-слониха, шалун-иалунья.

По поводу данного значения А. В. Плунгян отмечает: «С другой стороны, нельзя утверждать, что в русском языке у существительных (хотя бы у части) имеется обязательная категория естественного пола (с двумя значениями 'мужского пола' и 'женского пола'): «хороший» естественный подкласс одушевленных существительных в данном случае не годится - слишком многие названия людей и особенно животных не обладают в русском языке морфологическими средствами для выражения пола (ср. такие слова, как дизайнер, хирург, рысь, скунс, гиена, чайка и многие другие); те же из них, которые такими средствами обладают (ср. пары типа сосед - соседка, акробат - акробатка, медведь -медведиия, сквореч - скворчиха и т. п.) никаким другим, независимым, признаком в естественный класс не объединяются. Более того, даже в этих парах, строго говоря, противопоставляются не две словоформы, выражающие разные значения одной категории, а словоформа с неопределенным (или, в семиотических терминах, «немаркированным») значением - словоформе, выражающей значение 'женского пола': так, слово акробат, в отличие от слова акробатка, скорее всего означает просто 'человек определенной профессии...', а не ‘мужчина-акробат’ и т. п.; таким образом, морфологической категории здесь нет» [28, с. 108].

Естественный класс-животные, живые существа.

$\Gamma y c b$ - нейтральное (гуси) : гусак (мужской пол) : гусыня (женский пол).

Лис - нейтральное (лисы) : лисовин (мужской пол) : лисища (женский пол).

Поскольку мужской род склонен к нейтральности, совпадая со средним в формах косвенных падежей, а женский - маркирован, часто триада вырождается в пару: нейтральное/мужское : женское. Но для категории достаточно оппозиции нуля с единицей, т. е. женский пол : не-женский пол. Ср. прошедшее : не-прошедшее время; множ. : не-множественное число в императиве (стой-те : стой-ø).

Вспомним А. А. Зализняка и его падежи. Там тоже далеко не все слова имеют второй родительный падеж. Напротив - таких слов совсем немного.

Категория взрослости-невзрослости.

Маркирует названия детенышей: aucm - aucmeнок, слон-слоненок, волк-волчонок, змей-змееньи, гад-гаденыш. И здесь оппозиция нуля (взрослости) с единицей (не-взрослостью).

Собственно адъективная категория - категория подобия.

Прилагательные с суффиксами подобия имеют значение «содержащий что-либо, сходный с чем-либо, подобный чему-либо»: серныци - сернистый, песчаный - песчанистый, водяной - водянистый, кровяной - кровянистый, шелковый-шелковистый, травяной - травянистый, бельій - белёсый, чернылй - чернявый, смугльй-смуглявый.

\section{Контрпримеры}

На первый взгляд может показаться, что в русском языке имеется много суффиксов, по отношению к которым критерий определения их формо- или словообразовательного характера не срабатывает. Приведем некоторые примеры:

Музыка-музыкант, машина-машинист, бунт - бунтарь, север - северянин, сапог - сапожник, табун - табуншик, паркет - паркетчик, борода бородач, рог-рогаль, гора-взгорье, море-приморье, ритм - аритмия, лиса - лисица и др.

Это связано не только с гипнозом научной традиции, постулирующей внутричастеречное словообразование в русском и шире - в славянских языках, но и с тем, что словарный состав современного русского языка формировался на протяжении разных эпох под влиянием подсистем разных уровней языка, и со словообразовательной точки зрения не представляет однородной системы.

Например, семантика многих слов претерпела изменения по законам лексико-семантической системы. Эти инакосистемные (лексико-семантические) изменения не могут и не должны приписываться словообразовательной системе. Так, сапог - сапожник, табун - табунщчик, корова - коровник - не исключения, а ошибочно (с пропуском адъективного шага деривации) интерпретируемые слова: сапог сапожный мастер - сапожник; табун - табунский пастух - табунщик; корова - коровныйхлев-коровник. Такие слова можно назвать мнимо- или ложно-отсубстантивными. Восстановление же этого шага деривации позволяет нам расчленить морфемный блок-ник на составляющие-ьн (ср. бескоров-ный и Он бескоров-ен) и -ик. 
Кроме того, в речи встречаются не только исконно русские слова, но и заимствования разных периодов и из разных языков, которые отражают закономерности языков-источников. Современное русское словообразование представлено набором относительно самостоятельных, но взаимодействующих между собой подсистем - исконной подсистемы аффиксации апеллятивов (именно ее закономерности описаны выше), интернациональной подсистемы аффиксации (музыка - музыкант, машина - машинист, бунт - бунтарь), подсистемы аффиксации онимов, включающей неотъемлемые от нее притяжательные прилагательные с их производными (север - люди севера - северяне, поле человек поля - поляк, море - человек моря-моряк), а также подсистемы праиндоевропейского словообразования (мать - мачеха). Различение указанных подсистем позволяет объяснить многие мнимые исключения.

Слово аритмия и подобные слова никогда не образовывались в русском языке и также принадлежат интернациональной подсистеме, у которой все иное: и морфемы, и способы их соединения.

Что касается взгорья и приморья, то производящими для них являются предложно-падежные конструкции $в ъ з ъ+B . n$. существительного (въз гору) 'вверх по', зафиксированные в древних текстах и $п р и$ + П. $n$. существительного 'возле' (при море).

Наконец, лиса - лисица. Сравним форму множественного числа лисы - лисищьл. Лисы - это общее название для всех животных данного вида: лисицыь - это самки, лисовины - самцы и лисята - детеныши. В единственном числе оппозиция по полу дублируется и маркируется родом: лис - лиса, а во множественном - обе оппозиции (по полу и по взрослости) нейтрализуются.

\section{Выводы}

Таким образом, системную русскую морфологию можно представить, как совокупность подсистем.

Предлагаемые признаки различения морфологии-словообразования обобщены в таблице.

Т а б л и ц а

Основания разграничения словообразования, формообразования и словоизменения

\begin{tabular}{|l|l|l|l|}
\hline \multicolumn{1}{|c|}{ Раздел } & \multicolumn{1}{c|}{ Подраздел } & \multicolumn{1}{c|}{ Основа } & \multicolumn{1}{c|}{ Парадигма } \\
\hline Словообразование & \multicolumn{1}{c|}{-} & Изменяется & Изменяется \\
\hline \multirow{2}{*}{ Морфология } & Формообразование & Изменяется & Не изменяется \\
\cline { 2 - 5 } & Словоизменение & Не изменяется & Не изменяется \\
\hline
\end{tabular}

Так же, как в фонетике есть морфологизация и семасиологизация (лексикализация) чередований, так и в морфологии возможна морфологизация и семасиологизация (лексикализация) словоформ.

Словообразовательная система позволяет придавать лексической семантике разные синтаксические роли (функции).

Собственно словообразованием является лишь межчастеречное словообразование. Внутричастеречные аффиксальные образования маркируют грамматические категории и относятся к аффиксальному грамматическому формообразованию.

В свою очередь, предложенное понимание формообразования требует выделения в качестве морфологических категорий разрядов существительных и прилагательных, традиционно описываемых либо в качестве лексико-грамматических (единичность, собирательность), либо не описываемые совсем (категории пола, невзрослости - у существительных, подобия - у прилагательных).

\section{ЛИТЕРАТУРА}

1. Основные понятия морфемики // Русская грамматика : [в 2 т. / редкол.: Н. Ю. Шведова (гл. ред.) и др.]. М. : Наука, 1980. T. I. С. 121-410.

2. Герд А. С. Морфемика. СПб. : Изд-во Санкт-Петерб. ун-та, 2004. 176 с.

3. Николина Н. А., Рацибурская Л. В. Современный русский язык. Морфемика : учеб. пособие. М. : ФЛИНTA: Наука, 2013. 144 с.

4. Крылов С. А., Старостин С. А. Актуальные задачи морфологического анализа и синтеза в интегрированной информационной среде STARLING // Компьютерная лингвистика и интеллектуальные технологии : Труды международной конференции «Диалог-2003». М. : Наука, 2003. С. 354-360.

5. Азарх Ю. С. Словообразования и формообразование существительных в истории русского языка. М. : Наука, 1984. 248 с.

6. Богданов С. И. Форма слова и морфологическая форма. СПб. : Изд-во Санкт-Петерб. ун-та, 1997. 248 с.

7. Бондарко А. В. Формообразование, словоизменение и классификация морфологических категорий (на материале русского языка) // Вопросы языкознания. 1974. № 2. C. 3-15. 
8. Кубрякова Е. С. О формообразовании, словоизменениии и их соотношении // Изв. АН СССР. ОЛЯ. 1976. Т. 35, № 6. С. 514-527.

9. Морфология современного русского языка : учебник для высш. уч. заведений РФ / С. И. Богданов [и др.]. Санкт-Петерб. гос. ун-т. СПб., 2013. 640 с.

10. Фортунатов Ф. Ф. Сравнительное языковедение. (Общий курс) // Избранные труды. Т. 1. М., 1956. C. 155-267.

11. Щерба Л. В. Очередные проблемы языковедения // Избранные работы по языкознанию и фонетике. Л., 1958. С. 18-20.

12. Смирницкий А. И. Лексическое и грамматическое в слове // Вопросы грамматического строя. М., 1955. C. 11-53.

13. Виноградов B. В. Русский язык. Грамматическое учение о слове. Изд. 2-е. М. : Высшая школа, 1972. 614 с.

14. Кубрякова E. С. Асимметрия смысловых структур и отграничение словообразования от других типов морфологической деривации // Русский язык. Вопросы его истории и современного состояния. М., 1978. C. $18-30$.

15. Моисеев А. И. Основные вопросы словообразования в современном русском языке : учеб. пособие. Л., 1987. 207 c.

16. Шарандин А. Л. Общие вопросы русской морфологии. Теоретические основы и практикум : учеб. пособие. Тамбов : Издательский дом «Державинский», 2020. 164 c.

17. Мельчук И. А. Курс общей морфологии. Т. 1. Введение. Ч. 1. Слово : [пер. с фр.]. М. ; Вена : ЯРК: WSA (Sonderband 38/1): Прогресс, 1997.

18. Dressler $W$. U. Prototypical differences between inflection and derivation // Zeitschrift für Phonetik, Sprachwissenschaft und Kommunikationsforschung. 1989. 42: 1. S. 3-10.

19. Plank $F$. Inflection and derivation // Eurotyp Working Papers. Nheme 7: Noun Phrase Structure. Working Paper № 10. March 1991.

20. Перцов Н. В. Инварианты в русском словоизменении. М. : Языки русской культуры, 2001. 280 с.

21. Маслова E. C. О критерии обязательности в морфологии // Известия Российской Академии наук. Серия литературы и языка. 1994. Т. 53, № 3. С. 44-50.

22. Кретов $A$. $A$. Методические указания по курсу «Проблемы теории деривации» для слушателей ФПК. Воронеж, 1995. 32 с.

23. Руделев В. Г. Динамическая теория частей речи русского языка // Вестник Тамб. ун-та. Сер.: Гуманитарные науки. 1996. № 1. С. 83-89.

24. Руделева О. А., Руделев В. Г. Существительное и наречие (на материале русского языка) // Вестник Воронеж. гос. ун-та. Сер.: Лингвистика и межкультурная коммуникация. 2010. № 2. С. 17-23.

25. Зализняк A. A. «Русское именное словоизменение» с приложением избранных работ по современному русскому языку и общему языкознанию. М. : Языки славянской культуры, 2002. 752 с.
26. Шахматов A. А. Очерк современного русского литературного языка : учебник для вузов / под ред. и с примеч. С. П. Обнорского. М. : Юрайт, 2017. 235 с. Сер.: Антология мысли.

27. Дементьев А. А. Очерки по словообразованию имен существительных в русском языке (имена существительные с суффиксами -ок, -ка, -ко, -ец, -ца, -цо, -ицуа, -ице ) // Учебные записки Куйбышев. гос. пед. инта им. В. В. Куйбышева. 1959. Вып. 27. С. 5-181.

28. Плунгян В. А. Общая морфология : введение в проблематику. М. : Эдиториал УРСС, 2000. 384 с.

\section{REFERENCES}

1. Osnovnye ponyatiya morfemiki [Basic concepts of morphemics]. In: Russkaya grammatika [Russian grammar] : [V 2-x t. / Redkol.: N. Y. SHvedova (gl. red.) i dr.]. M. : Nauka, 1980. Vol. I. Pp. 121-410.

2. Gerd A. S. Morfemika [Morphemics]. SPb.: Izd-vo S.-Peterb. un-ta, 2004. 176 p.

3. Nikolina N. A., Ratsiburskaya L. V. Sovremennyj russkij yazyk. Morfemika: ucheb. posobie [Modern Russian language. Morphemics]. M.: FLINTA: Nauka, 2013. 144 p.

4. Krylov S. A., Starostin S. A. Aktual'nye zadachi morfologicheskogo analiza i sinteza $\mathrm{v}$ integrirovannoj informatsionnoj srede STARLING [Current problems of morphological analysis and synthesis in the STARLING integrated information environment]. In: Komp'yuternaya lingvistika i intellektual'nye tekhnologii: trudy mezhdunarodnoj konferentsii Dialog'2003. M.: Nauka M., 2003. Pp. 354-360.

5. Azarkh Yu. S. Slovoobrazovaniya i formoobrazovanie sushhestvitel'nykh v istorii russkogo yazyka [Word Formations and Noun Formation in the History of the Russian Language]. M.: Nauka, 1984. 248 p.

6. Bogdanov S. I. Forma slova i morfologicheskaya forma [Word form and morphological form]. SPb.: Izd-vo S.-Peterb. un-ta, 1997. 248 p.

7. Bondarko A. V. Formoobrazovanie, slovoizmenenie i klassifikatsiya morfologicheskikh kategorij (na materiale russkogo yazyka) [Form Formation, word modification and classification of morphological categories (based on the material of the Russian language)]. In: Voprosy yazykoznaniya. 1974. No. 2. Pp. 3-15.

8. Kubryakova E. S. O formoobrazovanii, slovoizmeneniii i ikh sootnoshenii [On the formation, inflection, and their relationship]. In: Izv. AN SSSR. OLYA. 1976. Vol. 35, No. 6. Pp. 514-527.

9. Morfologiya sovremennogo russkogo yazyka / Bogdanov S. I., Evtyukhin V. B., Knyazev Yu. P., Smirnov Yu. B., Ryzhova Yu. V., Voejkova M. D. Ucheb-k dlya vyssh. uch. zavedenij RF [Morfologiya sovremennogo russkogo yazyka]. Sankt-Peterburgskij gos. un-t. SanktPeterburg, 2013. 640 p.

10. Fortunatov F. F. Sravnitel'noe yazykovedenie. (Obshhij kurs). In: Izbrannye trudy [Comparative linguistics. (General course)]. Vol. 1. M., 1956. Pp. 155-267. 
11. SHHerba L. V. Ocherednye problemy yazykovedeniya [The next problems of linguistics]. In: Izbrannye raboty po yazykoznaniyu i fonetike. L., 1958. Pp. 18-20.

12. Smirnitskij A. I. Leksicheskoe i grammaticheskoe $v$ slove [Lexical and grammatical in a word]. In: Voprosy grammaticheskogo stroya. M., 1955. Pp. 11-53.

13. Vinogradov V. V Russkij yazyk. Grammaticheskoe uchenie o slove [Russian language. Grammatical teaching about the word]. Izd. 2-e. M.: Vysshaya shkola, 1972. 614 p.

14. Kubryakova E. S. Asimmetriya smyslovykh struktur i otgranichenie slovoobrazovaniya ot drugikh tipov morfologicheskoj derivatsii [Asymmetry of semantic structures and differentiation of word formation from other types of morphological derivation]. In: Russkij yazyk. Voprosy ego istorii i sovremennogo sostoyaniya. M., 1978. Pp. 18-30.

15. Moiseev A. I. Osnovnye voprosy slovoobrazovaniya v sovremennom russkom yazyke. Uchebnoe posobie [The main issues of word formation in the modern Russian Language]. L., 1987. 207 p.

16. SHarandin A. L. Obshhie voprosy russkoj morfologii. Teoreticheskie osnovy i praktikum: uchebnoe posobie [General questions of Russian morphology. Theoretical foundations and practical training]. Tambov: Izdatel'skij dom «Derzhavinskij», 2020. 164 p.

17. Mel'chuk I. A. Kurs obshhej morfologii. T. 1. Vvedenie. CH. 1. Slovo [Melchuk I. A. Course of general morphology. Vol. 1. Introduction. Ch. 1. Word]. M.; Vena: YARK: WSA (Sonderband 38/1): Progress, 1997 [per. s frants.].

18. Dressler W. U. Prototypical differences between inflection and derivation. In: Zeitschrift für Phonetik, Sprachwissenschaft und Kommunikationsforschung. 1989. 42: 1. Pp. 3-10.

19. Plank F. Inflection and derivation. In: Eurotyp Working Papers. Nheme 7: Noun Phrase Structure. Working Paper № 10. March 1991.

20. Pertsov N. V. Invarianty v russkom slovoizmenenii [Invariants in Russian inflection]. M.: YAzyki russkoj kul'tury, 2001. 280 p.

Воронежский государственный университет Меркулова И. А., доктор филологических наук, доцент кафедры теоретической и прикладной лигнвистики

E-mail: igel1@yandex.ru

Поступила в редакциию 19 февраля 2021 г.

Принята к публикачии 22 марта 2021 г.

\section{Для цитирования:}

Меркулова И. А. Аффиксальное формообразование русского имени // Вестник Воронежского государственного университета. Серия: Лингвистика и межкультурная коммуникация. 2021. № 2. C. 143-153. DOI: https:// doi.org/10.17308/lic.2021.2/3424
21. Maslova E. S. O kriterii obyazatel'nosti v morfologii [About the mandatory criteria in morphology]. In: Izvestiya Rossijskoj Akademii nauk. Seriya literatury i yazyka. 1994. Vol. 53, No. 3. Pp. 44-50.

22. Kretov A. A. Metodicheskie ukazaniya po kursu "Problemy teorii derivatsii» dlya slushatelej FPK [Methodological guidelines for the course "Problems of the theory of derivation" for students]. Voronezh, 1995. $32 \mathrm{p}$.

23. Rudelev V. G. Dinamicheskaya teoriya chastej rechi russkogo yazyka [Dynamic theory of parts of speech in the Russian language]. In: Vestnik Tambovskogo universiteta. Seriya: gumanitarnye nauki. 1996. No. 1. Pp. 83-89.

24. Rudeleva O. A., Rudelev V. G. Sushhestvitel'noe i narechie (na materiale russkogo yazyka) [Noun and adverb (based on the material of the Russian language)]. In: Vestnik VGU. Seriya: lingvistika i mezhkul'turnaya kommunikatsiya. 2010. No. 2. Pp. 17-23.

25. Zaliznyak A. A. "Russkoe imennoe slovoizmenenie" s prilozheniem izbrannykh rabot po sovremennomu russkomu yazyku i obshhemu yazykoznaniyu [Russian Russian nominal inflection with the application of selected works on the modern Russian language and general linguistics]. M.: YAzyki slavyanskoj kul'tury, 2002. $752 \mathrm{p}$.

26. SHakhmatov A. A. Ocherk sovremennogo russkogo literaturnogo yazyka : uchebnik dlya vuzov [An essay on the modern Russian literary language]. M.: Izdatel'stvo YUrajt, 2017. 235 p. Seriya : Antologiya mysli.

27. Dement'ev A. A. Ocherki po slovoobrazovaniyu imen sushhestvitel'nykh $\mathrm{v}$ russkom yazyke (imena sushhestvitel'nye s suffiksami -ok, -ka, -ko, -ets, -tsa, -tso, -itsa, -itse) [Essays on the word formation of nouns in the Russian language]. In: Uch. zap. Kujbyshevskogo gos. ped. in-ta imeni V.V. Kujbysheva. 1959. Vyp. 27. Pp. 5-181.

28. Plungyan V. A. Obshhaya morfologiya: Vvedenie v problematiku [Plungyan V. A. General morphology: Introduction to problematics]. M.: EHditorial URSS, 2000. 384 p.

Voronezh State University

Merkulova I. A., Doctor of Philology, Associate Professor of the Theoretical and Applied Linguistics Department

E-mail:igel1@yandex.ru

Received: 19 February 2021

Accepted: 22 March 2021

\section{For citation:}

Merkulova I. A. Affixation derivation of Russian nouns. Proceedings of Voronezh State University. Series: Linguistics and Intercultural Communication. 2021. No. 2. Pp. 143-153. DOI: https://doi.org/10.17308/lic.2021.2/3424 